Article

\title{
The Baleen Whales' Saving Grace: The Introduction of Petroleum Based Products in the Market and Its Impact on the Whaling Industry
}

\author{
John McCollough * and Henry F. Check, Jr. \\ Department of Business and Economics, The Pennsylvania State University-Lehigh Valley, \\ 2809 Saucon Valley Rd., Center Valley, PA 18034, USA; E-Mail: hfc3@psu.edu \\ * Author to whom correspondence should be addressed; E-Mail: jdm37@ psu.edu; \\ Tel.: +1-610-285-5120; Fax: +1-610-285-5220.
}

Received: 16 August 2010; in revised form: 22 September 2010 / Accepted: 26 September 2010 / Published: 30 September 2010

\begin{abstract}
This paper presents empirical evidence which indicates that the introduction of petroleum based products on the American markets was a significant factor in reducing the demand for whale oil. As a result, the whaling industry, America's 5th largest industry at the time, soon collapsed. A counterfactual study is then presented which suggests that if the introduction of petroleum based products had been delayed, then the increase in demand as a result of rising GDP per capita, as well as rapid industrialization, would have given whalers incentive to continue chasing after a diminishing whale population. This could have resulted in the baleen whale population being subject to unsustainable harvest levels.
\end{abstract}

Keywords: sustainable yield; whaling; sperm whales; baleen whales

\section{Introduction}

This paper presents an interesting case study of the American whaling industry during the 1800s. The whaling industry was a highly competitive, unregulated industry engaged in open access harvesting of a renewable resource. Although whaling was highly profitable, industry-wide harvest levels never reached the maximum sustainable yield of whale populations on an annual basis. Instead, by the end of the 1800s demand for whale bi-products had dried up causing the industry to fold. The primary cause for this decline was the introduction of petroleum based products onto the American markets. However, if the 
introduction of petroleum based products had been delayed, then would it have been possible for the whaling industry to eventually harvest beyond the maximum sustainable yield for certain whale species? This paper employs a counter factual analysis to empirically answer this question.

It is well known from the environmental economics literature that when individuals are engaged in the harvesting of either a renewable or non-renewable resource on common property grounds these individuals will tend to carry out a rapacious harvest, neglecting the cost they pose on the larger community, hence the Tragedy of the Commons. Therefore there is a need to regulate the harvesting of a natural resource within common property boundaries so that the resource is not harvested beyond the maximum sustainable yield.

However, from a classical point of view, regulation should be held to a minimum. The reason for this is that in the case of a natural renewable resource, as the population declines it becomes more and more difficult to harvest the remaining population. The more difficult it becomes, the more costly it becomes and, hence, the marginal cost associated with this activity begins to increase (assuming extraction technologies are held constant). This makes the harvesting of the resource less profitable to those engaged in the activity and they will then begin to refrain from the activity, which now gives the resource an opportunity to recover to more healthy population levels.

As Clark ([1], p. 951) points out, "It has been noted, that harvesting costs rise with decreasing population levels, a rent-maximizing policy will automatically lead to biological conservation, with an equilibrium population in excess of the population corresponding to maximum sustained yield". With respect to whaling in the 1800 s, Bardi ([2], p. 302) notes that "Evidently, the reduction in whale populations were sufficient to make whaling progressively more expensive and difficult, given the technology of whaling at that time."

For the most point, this classical argument makes a good deal of sense. However, continued harvesting of a natural renewable resource can occur at such a rate that market supply begins to diminish, which in turn can cause a rapid price increase. As the price increases, those engaged in the harvesting are encouraged to continue their efforts. For instance, the declining stocks of whales resulted in diminishing supplies (most noticeable with the harvests of the 1850s) which put continued upward pressure on prices. The higher price supported higher operating costs, encouraging and allowing whalers to continue hunting a smaller whale population. As Coleman ([3], p. 281) notes, "This projected higher price was enough to lure captains and their vessels into more dangerous areas looking for new and previously undiscovered pods of whales." Any new discovery led to profits that were "tremendous" and "soon 'everybody' had a ship on the new grounds" ([3], p. 281).

The classical argument also does not take into account other demand factors, such as rising incomes, populations, or changes in taste which can increase price, giving firms more incentive to harvest ever decreasing, and therefore, costlier remaining resources in question. A case in point can be seen with rising incomes, especially in fast developing economies, where increasing world demand puts upward pressure on today's oil prices. This upward pressure on prices gives oil firms incentives to drill in locations that were once cost prohibited.

Because of these considerations, governments need to continue vigilance in overseeing the harvesting of renewable resources on common property. Perman, Ma, and McGilvray ([4], p. 194) state that "in these circumstances, if the parameters of the demand function shift so that demand increases and the resource price becomes higher at any harvested quantity, the revenue function shown ... will have a 
higher maximum value. In this case, the open access equilibrium will exist at a lower resource stock level." However, it needs to be kept in mind that there are natural market forces that constrain prices from rising too high. This, of course, is the existence of substitute products, like coal or linseed oil, which could help to constrain the price of sperm and whale oil from rising too high [5].

For most of the 1800's, America was the undisputed leader in whaling, but in the late 1850s and early 1860s there were significant structural changes in the market for which whale bi-products competed, eventually resulting in the collapse of the American whaling industry by 1915 . These structural changes, for the most part, resulted from the introduction of cheaper, superior substitute products, in particular those from refined petroleum products (i.e., kerosene).

It is interesting to consider that the discovery of petroleum products, a major contributor to green house gas emissions, was instrumental in relieving much of the stress placed on the whale populations during the golden age of whaling. This historical analysis is also interesting in reminding us of the power that market forces have at holding down prices and reducing demand for a valuable commodity (such as petroleum oil in today's markets) when a competitively priced alternative product is introduced.

Following this introduction the paper will briefly review the whaling industry in terms of demand for its product as well as supply considerations for the industry. This review is necessary to establish the competitive nature of the industry. After the demand and supply analysis the paper then turns its attention to the estimation of whaling populations at the beginning of the 1800s as well as the total harvest and maximum sustainable yield figures of whaling populations in question. An empirical model is then presented so that forecasts of whale harvests can be projected based on the assumption that the introduction of both petroleum based kerosene and petroleum based lubricants onto the market could have been delayed for a period of years. A conclusion and discussion is then presented at the end of the paper.

\section{Market Analysis-Demand and Supply Considerations}

During the 1600 s, whaling was primarily a Dutch concern, but from 1750 to the early decades of the 1800s, England dominated the whaling industry. In 1816, the British had sent 150 vessels to harvest whales in the North Atlantic as compared to only two American vessels ([6], p. 144) However, within a span of just a few years, America dominated the whaling industry and maintained its preeminence from the 1820s to the first decades of the 1900s. Starting from the 1840s America was considered to hold a monopoly on whaling. By 1853 the whaling industry had become the 5th largest industry in America employing tens of thousands of workers. During this period American whaling hunted primarily five different kinds of whales. They were the sperm whale and four different types of baleen whales: the right, grey, bowhead, and the humpback.

After 1915, America played a limited role in the whaling industry as Norway and Japan started to dominate whaling. However, both Norway and Japan hunted different kinds of whales and for different purposes than did the Americans. For instance, Norway hunted the rorquel whales which provided Norway with a source of cooking oil and meat.

Both the industrial markets and the consumer markets drove the American demand for whale bi-products. These bi-products were sperm oil, whale oil, and whale bone. Sperm oil, produced by sperm whales, was used as a lubricant for light fast moving mechanical parts such as spindles. It was also used 
as an illuminant for lighthouses, street lamps, and public buildings. Whale oil (or tran oil), produced from baleen whales, was used as a lubricant for heavier machinery. Whale oil was also used as an illuminant for homes and as a cleansing agent. Finally whale bone, which is also produced from baleen whales, was used much like industrial plastic or "spring steel" is used today. In addition, whale bone was used in making corsets, skirts, and umbrellas.

Sperm and whale oil both had a number of substitute products. These were coal oil (the original kerosene; considered sooty, smelly and low quality), manufactured gas (derived from coal), camphene (derived from turpentine and alcohol), camphor oil (considered bright, sweet smelling, cheap yet volatile), lard oil (used as an illuminant and lubricant but more expensive than coal oil; considered low quality and smelly), linseed oil, and petroleum products (the "new" kerosene used in illumination and lubrication).

Coal oil was refined in the mid 1850's and eventually became cheaper than sperm \& whale oil. Wholesale price of coal oil in 1860 was $\$ 0.75$ a gallon. America started to substitute both coal oil and manufactured gas for whale and sperm oil by the mid 1850's. It was, however, refined petroleum that soon became the prime competitor to whale oil. A few years after the discovery in 1859 at Titusville, Pennsylvania, petroleum based products were refined into high quality illuminants and lubricants. By 1862 the petroleum industry, by making good use of an existing liquid fuel infrastructure, became well established [7]. Illuminating oil, which is kerosene, was the most important of all refined petroleum products. Table 1 below will give the reader some idea as to the dominant impact refined petroleum products had on the whale and sperm oil industries. Searching and drilling for petroleum oil had its risks, however, it was far less risky and more profitable to drill for petroleum oil than hunt for whales. Compared with whaling ventures Coleman ([3], p. 279) writes "Now it took fewer people less time to produce more crude at, or near, major markets or transportation systems."

Table 1. Decade averages on gallons of sperm and whale oil harvested as well as prices for sperm and whale oil (per gallon) and the price of petroleum (per barrel) $[8,9]$.

\begin{tabular}{|c|c|c|c|c|c|}
\hline Decade & $\begin{array}{c}\text { Sperm Oil } \\
\text { Gallons } \\
\text { (in millions) }\end{array}$ & $\begin{array}{c}\text { Price of } \\
\text { Sperm Oil } \\
\text { (in \$2008) }\end{array}$ & $\begin{array}{c}\text { Whale Oil } \\
\text { Gallons } \\
\text { (in millions) }\end{array}$ & $\begin{array}{c}\text { Price of } \\
\text { Whale Oil } \\
\text { (in \$2008) }\end{array}$ & $\begin{array}{c}\text { Price of } \\
\text { Petroleum } \\
\text { (in \$2008) }\end{array}$ \\
\hline $1820 \mathrm{~s}$ & 2.0 & 11.99 & 1.5 & 5.63 & \\
\hline $1830 \mathrm{~s}$ & 4.0 & 17.16 & 5.0 & 6.88 & \\
\hline $1840 \mathrm{~s}$ & 4.1 & 21.81 & 7.5 & 8.06 & \\
\hline $1850 \mathrm{~s}$ & 2.7 & 34.06 & 6.8 & 15.07 & 388.11 \\
\hline $1860 \mathrm{~s}$ & 1.7 & 31.64 & 2.8 & 15.07 & 77.43 \\
\hline $1870 \mathrm{~s}$ & 1.3 & 25.61 & 1.3 & 11.27 & 44.15 \\
\hline $1880 \mathrm{~s}$ & 0.76 & 19.45 & 0.86 & 10.48 & 19.45 \\
\hline $1890 \mathrm{~s}$ & 0.44 & 14.28 & 0.27 & 9.50 & 20.11 \\
\hline
\end{tabular}

Harvest of sperm oil for the American markets peaked in the 1840s with an annual average of 4.1 million gallons. The annual average harvest in the 1850 s was 2.7 million gallons and 440 thousand gallons of processed sperm oil by 1890 . The average price for sperm oil held up best during the 1850s. During that period the average price was $\$ 34.06$ a gallon (in 2008 dollars). By the 1890 s the average price for the decade had declined to $\$ 14.28$ a gallon (in 2008 dollars). The harvest of whale oil followed 
a similar pattern. The harvest for the American markets peaked in the 1840s at over 7.5 million gallons. The average harvest in the 1850s was close to 6.8 million gallons. After that the harvest dropped rapidly and by the 1890s the harvest of processed whale oil was just a fraction of its peak years. Prices for whale oil held up best during the 1850s and 1860s with prices at about $\$ 15.07$ a gallon (2008 dollars) but by the 1890s it was under $\$ 10$ a gallon (in 2008 dollars). Sperm and whale oil quantities and prices come from Tower [8]. Figures are based on a 31.5 gallon barrel.

The export market for sperm and whale oil was much more insignificant than the American market. "The overseas market, however, faced with rising supplies of first coal gas, then camphene, and finally kerosene and increasingly cut off by continental tariffs, never recovered from the interruption of the Civil War" ([10], p. 199).

With large petroleum reserves nearby, the price of petroleum in America plummeted. The average price of kerosene declined by over 75\% from 1865 to 1894 . Production of kerosene expanded rapidly. For instance, in 1865 the production was just under 1 million barrels. In 1870 the Standard Oil Company had "standardized" kerosene, making it safe for home consumption and by 1914 it was well over 46.5 million barrels. In 1862 the average wholesale price in current dollars was \$0.32 a gallon (compared to $\$ 1.43$ for sperm oil, $\$ 0.60$ for whale oil, and $\$ 0.75$ a gallon for coal oil in 1860 ) [7,8]. While the industry for petroleum based kerosene was expanding the production of sperm and whale oil was moving in the opposite direction in the last half of the 1800s. Eventually, due to competition from petroleum based products, the market for sperm and whale oil declined drastically in the decades following the Civil War and it never recovered to the prominence it displayed during its golden years.

Oddly enough, the market for whalebone held up well after the Civil War. The whaling industry's greatest level of production was achieved in the 1850s with close to 2.8 million pounds of whale bone harvested for American consumption. During these years the average price was $\$ 14.08$ a pound of whalebone (2008 dollars). Total industry production of whalebone fell for the rest of the century, however, per vessel catch (after declining for 30 years following the period of 1846-1855), picked up again from 1886-1905, almost to its golden-year levels.

The reason why per vessel harvest levels of whale bone returned to its golden-year levels had to be the steep increase in the price for a pound of whale bone from 1876-1906. This gave whalers a good incentive to continue harvesting whale bone despite declining whale oil prices. The price of a pound of whale bone averaged $\$ 20.57$ (2008 dollars) in the 1860s, but rose steadily for the rest of the century. In 1904, its price peaked at $\$ 140.70$ (2008 dollars). Soon after, however, the whalebone market collapsed. "In 1908 the introduction of flexible-form steel and a change in women's fashion caused the baleen market to collapse, and in 1915 only one whaler (with no reported catch) made a voyage to the western Arctic." ([11], p. 979).

An analysis of the whaling industry by Davis, Gallman, Hutchins ([10], pp. 217-222) shows it to be a highly competitive industry with a large number of supplying firms (thought of as whaling vessels) as well as a large number of entrepreneurs all producing a basic homogeneous commodity. By 1835 there were over 1,000 American vessels engaged in the harvesting of whales. Of these 1,000 vessels, 700 of them had their home port in the New Bedford area (New England) ([10], pp. 217-222). The remaining vessels were concentrated in port cities such as San Francisco and others.

Each whaling vessel could be considered an individual firm. A vessel was most likely to be owned by an agent, a firm, the captain, or any combination thereof. "Because the agents, the captain, and even the 
owners frequently changed from one voyage to the next, the vessel-voyage approximates the notion of a firm in economic theory, and is a particular useful unit of analysis" ([10], p. 193).

Agents typically managed the voyages, and often times the agents were the owners or at least part owners, but this is not true in all cases. Agents were responsible for "preparing the craft for sea: seeing to the renewal of the masts, spars and rigging, replacing lost or broken whalecraft, provisioning, and hiring the officers and men" while the ship was in port ([10], p. 217). A share of the net proceeds would depend "on how carefully the preparations for the voyage were carried out" ([10], p. 217).

Of the 275 agents associated with the New Bedford whaling industry, 197 managed 10 or fewer voyages. Agents were typically entrepreneurs who were engaged in other businesses as well. Some of these businesses were in markets totally unrelated to the markets for whale bi-products. The single largest agent was only involved in $3 \%$ of the voyages by himself. His joint ventures with other partners amounted to no more than thirteen percent of the total voyages originating from New Bedford ([10], pp. 220-221).

Costs incurred by the owner/agents included the cost of the vessel, which was a one time capital outlay that depreciated over time. The average age of a whaling vessel was somewhere between 38 and 47 years (depending on the type of vessel). Other costs were labor, crew provisions (i.e., food, etc.), ship maintenance supplies, whaling supplies (harpoons and small whalecraft for approaching the whales), etc. Labor, crew provisions, and maintenance supplies could be considered marginal cost, with labor being the largest cost of a voyage. Whaling supplies could be considered fixed costs since they could be reused repeatedly if not damaged or lost in the hunt.

Labor costs were a fraction of the net proceeds derived from the harvest and therefore were considered to be a constant marginal cost. The term for this fractional share of net proceeds was called a "lay". Each crew member would sign a contract before the voyage which stated his own fractional share of the proceeds. The individual "lay" would reflect the relative worth of the crew member. A crew member's earnings varied from voyage to voyage which depended on current market conditions as well as the total harvest.

It is important to know that throughout the 1800's the total lay of the entire crew for a typical voyage was pretty much constant. The total lay ranged between $30 \%-32 \%$, or just about a third of total revenues. There was a fifteen year period (from 1850-1865) where the total lay did creep up to about $36 \%$, but this was abnormally high. From 1840-1858, the average lay was still only $33.2 \%$ (this average included 8 of the 15 years of higher than normal lays) ([10], pp. 209-217).

Over a 90 year period, from 1816-1905, the American whaling industry returned to all American ports with over 176.6 million gallons of Sperm oil, over 264.9 million gallons of whale oil, and 81 million pounds of whale bone for American consumption [8]. Total industry revenue for the American market during the 90 year period was $\$ 8$ billion dollars (in 2008 dollars), or roughly $\$ 88.6$ million per year. Between 1826 and 1865 the American whalers returned to American ports with nearly 128 million gallons of Sperm oil per year, 218.2 million gallons of whale oil, and 66.8 million pounds of whale bone. During these years 2,325 voyages returned to whaling ports on the east coast ([10], pp. 199-201). The total harvest per boat, in terms of revenue, during this time period was $\$ 2.67$ million (2008 dollars). This dollar amount has to be taken in context. During this time period the average length of a voyage could have lasted anywhere from 2-3 years and not every whaling vessel returned with a full load of whale oil or whale bone. 
Despite the competitive nature of the industry, whaling was very profitable for those partaking in it. From 1816-1825 the average rate of return was 31.6\%. From 1826-1835 the average rate of return was $57.8 \%$. And from 1836 to 1842 , the average rate of return was $36.9 \%$. Overall, the average rate of return for the period of 1816-1842 was 42.7\% ([12], p. 110). One reason for such profitable returns was the nature of the business. Whaling was risky and dangerous and the harvest uncertain. The average loss rate of vessels at sea was 3.2\% per year. In one particularly bad year (1871) a fleet of 33 ships were trapped by ice off the North Coast of Alaska and destroyed costing the industry \$1.6 million dollars [3].

It is apparent from this review of the demand and supply factors facing the whaling industry that it was very competitive. There were numerous vessels engaged in harvesting both sperm and baleen whales with not a single agent large enough to exert control over the market. The industry product was a homogenous product with many substitutes. Although the profits were handsome, the reader has to be reminded of the risks involved with whaling.

\section{Maximum Sustainable Yield Estimates for the Sperm and Baleen Whales}

Both the populations of sperm and baleen whales prior to intensive commercial hunting have been estimated. Scarff [13] has estimated the sperm whale population prior to intensive commercial hunting to be 1.78 million while Allen [14] puts the sperm whale population at 2.4 million. Each sperm whale, on average, could yield 33.6 barrels of oil ([15], p. 579). Knowing the numbers of barrels bought back to port for American consumption and assuming a 10\% loss rate, Davis, Gallman, and Hutchins ([15], p. 579) estimate that between $8 \%$ and $18 \%$ of the initial stock of sperm whales were harvested over a 90 year period between 1804-1900 and that in the largest year of harvest the whalers only took less than half of one percent of the initial stock. This leaves Davis, Gallman, and Hutchins ([15], p. 579) to conclude that sperm whales during the golden age of whaling were not in trouble of being overharvested.

For the baleen whales it was a different story. Piecing together data from various scientists on the baleen whale sub-populations Davis, Gallman, and Hutchins ([15], p. 584) estimate that the initial stock of the baleen whale "probably originally numbered at least 367,000 ". Using an estimate of 73 barrels of whale oil per baleen whale and assuming a loss rate of $10 \%$ Davis, Gallman, and Hutchins ([15], pp. 584-585) estimate that nearly 180,000 baleen whales were harvested between 1804 and 1900. Furthermore, they find that American whalers never took more than 7,000 baleen whales in any given year. The natural rate of increase for baleen whales reaches its maximum at $60 \%$ of the population. Once the population drops below this number then the natural rate of increase begins to fall putting the population under stress and in jeopardy of not being able to repopulate back to its original levels. Therefore, for the baleen whales the population where the natural rate of increase is at its greatest would be $220,200(367,000 \times 0.60)([15]$, p. 586). Applying the natural rate of increase of the grey whales to the entire baleen whale population, estimated at .047 by Rice and Woolman [16], then this would mean that the maximum sustainable yield for the baleen whales as a group would be roughly 10,350 $(220,200 \times 0.047)$. It should be noted, however, that recent studies based on mitochondrial DNA tissue samples suggest that existing population estimates for specific baleen whale species before commercial exploitation might be seriously underestimated [17].

In their analysis, Davis Gallman, and Hutchins ([15], p. 587) conclude that the American whalers never reached the maximum sustainable yield for the baleen whales as a whole. However, they caution 
that they are applying the natural rate of increase found in the grey whales to other species of baleen whales and this might not be accurate. In addition, some breeding grounds could have been harvested more heavily than others as could some species of baleen whales. For instance, the grey whales, which yielded a relatively small amount of oil and bone versus the right whale, which could yield between 100-120 barrels of oil would make whalers want to concentrate more heavily on the right whale.

The analysis of Davis, Gallman, and Hutchins ([15], p. 591) suggests that with the existing technology both the worldwide stock of Sperm and Baleen whales were not in danger of being overharvested. However, this does not rule out the fact that individual stocks of whale populations were not overharvested. For instance, Allen and Keay [18] analyze how British and Dutch whalers managed to exploit the stock of Eastern Artic Bowhead whales off the coast of Greenland to extinction with less advanced whaling techniques than the Americans. British and Dutch whalers did enjoy government subsidies which made whaling more profitable for them. But Allen and Keay [18] find that the subsidies were not responsible for the extinction of the Greenland bowheads, rather it was the productive capabilities of the British Whalers. What is not clear, however, is if the British and Dutch whalers would have generated a large enough fleet without the various government subsidies.

\section{Empirical Modeling}

The quantity of whales harvested, both sperm and baleen, is a function of the number of whaling ships searching for whales as well as the number of whales available for harvest. The number of whaling ships searching for whales is a function of the expected profit from a whale harvest. Expected profit can be thought of as expected revenue less costs and that expected revenue is equal to expected price times expected quantity. Expected price can be estimated via an inverse demand equation where expected price is a function of the price of substitute products, real GDP per capita, as well as population levels. The expected quantity is a function of the change in the two previous harvests. If the most recent year's harvest has increased over the prior year's harvest, then owners (as well as the crew) are more enthusiastic to continue whaling operations. On the other hand, if the most recent harvest has decreased from the prior year's harvest, then owners will not be as enthusiastic to oversee another voyage. In addition, the whale population available for harvest is in part, dependent upon the cumulative changes of the harvest in prior years.

The main costs in whaling were the cost of the whaling ship itself, supplies and provisions for the voyage, as well as labor costs. The whaling ship was a one-time capital expenditure. Since whaling ships did not have any other marine purpose other than whaling, the opportunity cost for a whaling ship was limited. Therefore, the capital expenditure, considered a sunk cost, would not weigh in on the decision to partake in another voyage. Only those costs directly associated with a whaling voyage would play a part in that decision. The major cost of a voyage was labor with voyage supplies and provisions being considered an insignificant part of the overall cost of a voyage.

As stated previously, labor in the whaling industry, unlike many other trades, was paid a percentage of the harvest. This made the decision for the ship's owner to manage another voyage very simple. If the ship came back empty, then the owner did not incur any labor cost. The owner only incurred the cost of provisioning the voyage. However, the owner would still need to find a crew willing to take on the risks of a lengthy voyage. If the ship came back with an insufficient harvest, then the crew received less 
money. Also, if wages were rising in other trades relative to whaling wages, then the opportunity cost of whaling would rise for crew members. Both of these events could cause the crew to demand a higher percentage of the revenue from the harvest which in turn would reduce the owner's profits, giving owners less incentive to continue their whaling operations.

With these considerations in mind, the empirical model for the quantity of either whale or sperm oil for the period of 1807-1858 can be specified and follows;

$$
\mathrm{Qty}_{\mathrm{x}}=\mathrm{a}+\mathrm{b}_{1} \mathrm{Y}+\mathrm{b}_{2} \mathrm{P}_{\mathrm{x}}+\mathrm{b}_{3} \mathrm{~W}+\mathrm{b}_{4} \mathrm{~T}+\mathrm{b}_{5} \mathrm{~L}+\mathrm{b}_{6} \mathrm{Pop}+\mathrm{b}_{7} \mathrm{Qty}_{\mathrm{s}(\mathrm{t} 1-\mathrm{t} 2)}+\mathrm{b}_{8} \mathrm{Qty} \mathrm{w}_{\mathrm{w}(\mathrm{t} 1-\mathrm{t} 2)}+\mathrm{b}_{9} \mathrm{Qty} \mathrm{b}_{\mathrm{b}(\mathrm{t} 1-\mathrm{t} 2)}
$$

where:

Qty $_{X}=$ quantity of either sperm or baleen whale oil

$\mathrm{Y}=$ GDP per capita

$\mathrm{P}_{\mathrm{X}}=$ average price of either sperm or whale oil

$\mathrm{W}=$ index of unskilled wages in selected trades (used as a proxy to represent the opportunity cost for crew members to engage in a lengthy voyage)

$\mathrm{T}=$ average price of turpentine per gallon (primary ingredient for camphene)

$\mathrm{L}=$ average price of linseed oil per gallon

Qty $_{\mathrm{s}(\mathrm{t} 1-\mathrm{t} 2)}=$ change in quantity from the previous two harvests of sperm oil

Qty $_{\mathrm{w}(\mathrm{t} 1-\mathrm{t} 2)}=$ change in quantity from the previous two harvests of whale oil

$\mathrm{Qty}_{\mathrm{b}(\mathrm{t} 1-\mathrm{t} 2)}=$ change in quantity from the previous two harvests of whale bone

Regressions were run for two different time periods. The first was the period of 1807 through 1858, the year before petroleum was discovered in Titusville, Pennsylvania. The second regression was run for the period of 1859 through 1905. After 1859 the market for both sperm and whale oil began to fall apart due to the introduction of petroleum based products on the market. The explanatory variables are lagged one year before the dependent variable due to the length of a typical voyage. Table 2 below displays the empirical results for the harvest of sperm oil.

Table 2. Two Stage Least Squares result on the quantity of sperm oil between the years 1807-1858.

\begin{tabular}{|c|c|c|c|c|c|c|}
\hline \multicolumn{2}{|c|}{} & \multicolumn{2}{|c|}{ Unstandardized Coefficients } & \multirow{2}{*}{ Beta } & \multirow{2}{*}{ T } & \multirow{2}{*}{ Sig. } \\
\cline { 3 - 7 } & (Constant) & -9104.260 & 2537.278 & & -3.588 & 0.001 \\
\hline \multirow{5}{*}{ Equation 1 } & B & Std. Error & & & \\
\cline { 2 - 7 } & real_GDP_per_capita & 11.139 & 1.955 & 2.176 & 5.698 & 0.000 \\
\cline { 2 - 7 } & price_spermoil & -843.131 & 396.189 & -0.720 & -2.128 & 0.040 \\
\cline { 2 - 7 } & price_whaleoil & -2739.317 & 643.193 & -1.012 & -4.259 & 0.000 \\
\cline { 2 - 7 } & unskilled_wages & 7.326 & 14.123 & 0.059 & 0.519 & 0.607 \\
\cline { 2 - 7 } & price_turpentine & -1134.951 & 779.026 & -0.249 & -1.457 & 0.153 \\
\cline { 2 - 7 } & price_linseedoil & 294.154 & 587.289 & 0.055 & 0.501 & 0.619 \\
\cline { 2 - 7 } & Qtys(t1-t2) & 0.183 & 0.198 & 0.100 & 0.926 & 0.360 \\
\cline { 2 - 7 } & Qtyw(t1-t2) & -0.265 & 0.119 & -0.329 & -2.217 & 0.033 \\
\cline { 2 - 7 } & Qtyb(t1-t2) & 0.303 & 0.249 & 0.182 & 1.220 & 0.230 \\
\cline { 2 - 7 } & adjusted Rsq =0.513 & & & & & \\
\hline
\end{tabular}


Commodity prices for linseed oil and turpentine came from 2 sources. They are: Cole, A.H., "Wholesale Commodity Prices in the United States, 1700-1861" [19] and Bezanson, A., "Wholesale prices in Philadelphia, 1852-1896" [20]. GDP per capita came from "What was the GDP back Then." Source: Johnston, L.; Williamson, S.H. "What was the U.S. GDP then?" Measuring Worth, 2010. URL: http://www.measuringworth.org/usqdp/ [21]. All commodity prices for the purposes of the regression analysis were based in 1967 dollars.

The empirical results show that real GDP per capita is both positive and highly significant with respect to the quantity of sperm oil. During this period of America's industrial development the demand for illumination increased with the growth of cities and mass urbanization. In addition, industry also required great amounts of sperm and whale oil lubricants as the number of machines and equipment with fast moving parts increased due to America's rapid industrialization. This phase of industrial growth finds GDP per capita almost doubling between1805-1858.

The whaling industry was interested in both sperm whales and baleen whales. The empirical results find that the price of sperm oil and the price of whale oil to be both negative and highly significant with respect to sperm oil harvested. The negative relationship between the price of whale oil and the quantity of sperm oil shows the interrelationship between these two products. This relationship suggests that as the market price of whale oil would rise, whalers would shift their focus from harvesting sperm whales to harvesting more baleen whales. The opposite reasoning is also implied. That is, as the price of whale oil decreased then whalers would shift their focus, leaving certain baleen whaling grounds in search of sperm whales.

The index of wages for unskilled workers, used as a proxy for the opportunity costs faced by crew members, is insignificant for the time period of 1805-1858. Whaling, as previously mentioned, was an extremely well paying trade. As long as the harvests were bountiful and as long as sperm and whale oil prices held up, then it appears that owners did not have trouble attracting crew members.

The empirical results find both the price of linseed oil and turpentine had an insignificant impact on the sperm oil market. This demonstrates that both products, although considered substitutes for sperm and whale oil, where actually inferior to sperm and whale oil. The empirical results also finds that a change in the prior two years of harvest for sperm oil and whale bone did not have an impact on the current year's harvest of sperm oil. However, the change in the harvest between the previous two years for whale oil had a negative and significant relationship on the current year's harvest of sperm oil, suggesting that an increased harvest in whale oil from the previous two whaling seasons tends to redirect the current year's harvesting efforts from sperm whales to baleen whales.

The empirical results for whale oil are similar to the results for sperm oil for the time period of 1807-1858. Table 3 below displays the empirical results. Real GDP per capita, the price of whale oil, as well as the price of sperm oil are highly significant with the slope coefficients showing the correct predicted relationship. Once again, the negative sign on the price of sperm oil demonstrates that as the price of sperm oil would increase whalers would shift their focus from harvesting baleen whales to harvesting sperm whales. 
Table 3. Two Stage Least Squares result on the quantity of whale oil between the years 1807-1858.

\begin{tabular}{|c|c|c|c|c|c|c|}
\hline & \multicolumn{2}{|c|}{ Unstandardized Coefficients } & \multirow{2}{*}{ Beta } & \multirow{2}{*}{$\mathbf{T}$} & \multirow{2}{*}{ Sig. } \\
\hline & & B & Std. Error & & & \\
\hline \multirow{11}{*}{ Equation 2} & (Constant) & -18027.587 & 3904.992 & & -4.617 & 0.000 \\
\hline & Real_GDP_per_capita & 19.066 & 3.008 & 1.801 & 6.337 & 0.000 \\
\hline & price_whaleoil & -2455.322 & 989.904 & -0.439 & -2.480 & 0.018 \\
\hline & price_spermoil & -1263.241 & 609.754 & -0.522 & -2.072 & 0.045 \\
\hline & unskilled_wages & 5.177 & 21.736 & 0.020 & 0.238 & 0.813 \\
\hline & price_turpentine & -1953.792 & 1198.959 & -0.207 & -1.630 & 0.111 \\
\hline & price_linseedoil & 106.084 & 903.866 & 0.010 & 0.117 & 0.907 \\
\hline & Qtys(t1-t2) & -0.410 & 0.305 & -0.108 & -1.346 & 0.186 \\
\hline & Qtyw(t1-t2) & -0.481 & 0.184 & -0.289 & -2.616 & 0.013 \\
\hline & $\mathrm{Qtyb}(\mathrm{t} 1-\mathrm{t} 2)$ & 1.146 & 0.383 & 0.333 & 2.994 & 0.005 \\
\hline & adjusted Rsq $=0.887$ & & & & & \\
\hline
\end{tabular}

The price of turpentine has a negative relationship to whale oil (which is counterintuitive), and is slightly insignificant with a "p" value of $11 \%$ while the index of wages for unskilled workers and the price of linseed oil are insignificant.

Like the empirical results on sperm oil, the change in the harvest of sperm oil from the two most recent years has a negative relationship on the quantity harvested of whale oil, however this relationship is insignificant at the $18.6 \%$ level. The coefficient on the change in harvest for whale oil is expected to be positive. This would suggest that an increase in harvest between the two most recent years would cause whalers to continue to focus harvesting efforts on baleen whales. However, the empirical results show the coefficient to be negative and significant. But the change in the harvest of whale bone (a bi-product from the harvest of whale oil) is positive and significant, which was expected. This indicates that an increase in harvest for whale bone over the past two years would encourage whalers to harvest more baleen whales.

The specification for the empirical model for the period of 1859-1905 is the same as that for the period of 1807-1858 except that the price of petroleum was added as an explanatory variable. Starting in 1859 petroleum products became commercially available. The empirical results for sperm oil are displayed in Table 4.

The empirical results from the regression run after the introduction of petroleum based products onto the market show that the price of petroleum is both positive and significant at the $1 \%$ level. These results strongly attest to the disruptive impact petroleum had on the whaling industry. Petroleum oil soon overtook both sperm and whale oil as the major source of illuminating oil and lubricant for the economy. The dramatic misfortunes of the whaling industry after 1859 meant that even rising incomes for the population could not generate enough demand for whale and sperm oil to remain viable in the marketplace. This is demonstrated by the fact that after 1859 the coefficient on real GDP per capita turned from positive to negative for sperm oil, indicating that sperm oil could no longer be classified as a normal good but rather an inferior good. The income coefficient for whale oil also turned negative and insignificant (see Table 5) after the introduction of petroleum based products. The Chow test further 
attests to the significance of a structural break in the regression equation parameters after 1859 with the F-statistic for the sperm oil time series being 10.22 and the F-statistic for the baleen whale oil time series being 9.22. Both F-statistics indicate a structural break at a significance level of less than $1 \%$.

Table 4. Two Stage Least Squares result on the quantity of sperm oil between the years 1859-1905.

\begin{tabular}{|c|c|c|c|c|c|c|}
\hline & \multicolumn{2}{|c|}{ Unstandardized Coefficients } & \multirow{2}{*}{ Beta } & \multirow{2}{*}{$\mathbf{T}$} & \multirow{2}{*}{ Sig. } \\
\hline & & B & Std. Error & & & \\
\hline \multirow{12}{*}{ Equation 3} & (Constant) & 1929.027 & 640.932 & & 3.010 & 0.005 \\
\hline & price_petro & 15.972 & 4.877 & 0.215 & 3.275 & 0.002 \\
\hline & real_GDP_per_capita & -0.232 & 0.116 & -0.301 & -2.003 & 0.053 \\
\hline & price_spermoil & 318.130 & 83.877 & 0.505 & 3.793 & 0.001 \\
\hline & price_whaleoil & -256.548 & 170.643 & -0.154 & -1.503 & 0.142 \\
\hline & unskilled_wages & -5.448 & 5.850 & -0.107 & -0.931 & 0.358 \\
\hline & price_turpentine & 94.298 & 49.071 & 0.176 & 1.922 & 0.063 \\
\hline & price_linseed & 1.782 & 226.294 & 0.001 & 0.008 & 0.994 \\
\hline & Qtys $(\mathrm{t} 1-\mathrm{t} 2)$ & 0.149 & 0.121 & 0.074 & 1.224 & 0.229 \\
\hline & Qtyw(t1-t2) & -0.006 & 0.079 & -0.006 & -0.079 & 0.937 \\
\hline & $\mathrm{Qtyb}(\mathrm{t} 1-\mathrm{t} 2)$ & -0.578 & 0.317 & -0.149 & -1.825 & 0.077 \\
\hline & adjusted $\mathrm{Rsq}=0.887$ & & & & & \\
\hline
\end{tabular}

Table 5. Two Stage Least Squares result on the quantity of whale oil between the years 1859-1905.

\begin{tabular}{|c|c|c|c|c|c|c|}
\hline & \multicolumn{2}{|c|}{ Unstandardized Coefficients } & \multirow{2}{*}{ Beta } & \multirow{2}{*}{$\mathbf{T}$} & \multirow{2}{*}{ Sig. } \\
\hline & & $\mathbf{B}$ & Std. Error & & & \\
\hline \multirow{12}{*}{ Equation 4} & (Constant) & 987.465 & 1494.439 & & 0.661 & 0.513 \\
\hline & price_petro & 68.281 & 11.371 & 0.455 & 6.005 & 0.000 \\
\hline & real_GDP_per_capita & -0.261 & 0.270 & -0.168 & -0.970 & 0.339 \\
\hline & price_whaleoil & -26.133 & 397.883 & -0.008 & -0.066 & 0.948 \\
\hline & price_spermoil & 463.899 & 195.572 & 0.365 & 2.372 & 0.023 \\
\hline & unskilled_wages & -7.475 & 13.641 & -0.073 & -0.548 & 0.587 \\
\hline & price_turpentine & 68.297 & 114.418 & 0.063 & 0.597 & 0.554 \\
\hline & price_linseed & 249.335 & 527.642 & 0.098 & 0.473 & 0.639 \\
\hline & Qtys $(\mathrm{t} 1-\mathrm{t} 2)$ & -0.020 & 0.283 & -0.005 & -0.071 & 0.944 \\
\hline & Qtyw(t1-t2) & -0.215 & 0.184 & -0.103 & -1.170 & 0.250 \\
\hline & $\mathrm{Qtyb}(\mathrm{t} 1-\mathrm{t} 2)$ & 0.236 & 0.739 & 0.030 & 0.319 & 0.752 \\
\hline & adjusted $\mathrm{Rsq}=0.849$ & & & & & \\
\hline
\end{tabular}

As the petroleum industry began to develop, the price of petroleum began to decrease. This impacted both the price of whale oil and sperm oil as the whale industry began to collapse. The coefficient on the price of whale oil turned insignificant after 1859 while the coefficient on the price of sperm oil turned from negative to positive after the introduction of petroleum based products. To test the strength of the petroleum price effect the standardized residuals were examined for the 1859-1905 time series. Using 
the conventional rule-of-thumb of two standard deviations constituting an outlier, 18 outliers were found in the 21 years after 1859 in the sperm oil data, and 5 outliers in the 9 years after 1859 in the whale oil data. There were no outliers after those observations. This indicates that the discovery of oil had a significant and long lasting effect on the whaling industry, particularly with respect to the sperm oil market.

The coefficients on both the price of turpentine and linseed oil were positive, as expected, however only the price turpentine was significant while linseed oil was insignificant. Unskilled wages was negative, as anticipated, but insignificant. Finally, with respect to the change in harvest levels, only the change in the harvest of whalebone from the previous two periods was significant. Its sign was also negative, indicating that an increase in the harvest of whalebone from the prior two years would cause whalers to redirect their efforts away from the harvest of sperm whales towards harvesting baleen whales. Of course, a decrease in the harvest of whalebone would have the opposite effect and cause whalers to intensify their harvesting efforts of sperm whales.

The empirical results for whale oil are similar to the results for sperm oil for the time period of 1859-1905. Table 5 displays the empirical results below. As with the harvest of sperm oil after 1859, the price of petroleum had a positive and significant impact on the harvest of whale oil. The coefficient for GDP per capita turned from positive and significant to negative and insignificant after 1859. The coefficient on the price of whale oil became insignificant after 1859 while the coefficient on the price of sperm oil turned positive (although still significant). The remaining explanatory variables in the two stage least square regression were insignificant.

Assume for the moment that technological discoveries are random events throughout history and that the discovery of oil in Titusville, Pennsylvania could just as likely have been delayed by two decades. Then by 1880 what would the annual sperm and baleen whale oil harvest have looked like? Based on the results from Tables 2 and 3, GDP per capita was a significant contributor to the demand for both sperm and whale oil. Is it possible that rising incomes in America could have stimulated enough demand to generate harvesting rates beyond the maximum sustainable yield? The regression results for the time period between 1807 and 1858 shows that for every dollar increase in GDP per capita the harvest of sperm oil would have increased by 11,139 gallons and that the harvest of whale oil would have increased by an additional 19,066 gallons.

From 1858 to 1880 GDP per capita increased by $\$ 1,148$ (in 2000 dollars). Assuming a linear relationship between the demand of sperm oil and GDP per capita, the harvest for sperm oil would have increased by 12,787,572 gallons over its 1858 level of 3,441,522 million gallons of consumption in 1858 . This would have been a total harvest of 16,229,094 gallons of sperm oil or 515,209.33 barrels in 1880 . Of course, this is assuming that the price of sperm oil, as well as, the price of all substitute products are held constant and that petroleum had not yet been discovered.

Based on Davis, Gallman, and Hutchins ([15], p. 579) figures that a sperm whale on average would yield 33.6 barrels of oil, then it appears that the 1880 harvest would have been 15,333.61 sperm whales. Using the more conservative estimate of an initial population for sperm whales of 1.8 million, this means that the harvest would have still been less than $1 \%$ of the initial population ([15], p. 577). This estimated harvest figure means that the sperm whale would still not have been in jeopardy by 1880 .

The story is different for the baleen whales. Assuming the same linear relationship between the demand for whale oil and GDP per capita, and by holding the price of whale oil and all other substitute 
commodity prices constant, harvest of whale oil would have increased by 21,887,768 gallons from its 1858 level of 7,653,366 gallons. This would have put the 1880 demand for whale oil at 29,541,134 gallons or 937,813.77 barrels.

Using Davis, Gallman, and Hutchins ([15], p. 584) figures that an average baleen whale would yield 73 barrels, then the 1880 harvest would have seen 12,846 baleen whales harvested. Davis, Gallman, and Hutchins ([15], p. 587) estimated the maximum sustainable yield for baleen whales to be 10,350 . They also report that American whalers never took more than 7,000 baleen whales in a given year. However, based on this linear extrapolation, it is apparent that had the discovery of petroleum been delayed until 1880 then there was a good chance that demand for baleen whales, due to rising incomes, would have exceeded the maximum sustainable yield.

It should be noted that the maximum sustainable yield (MSY) is often criticized by some as a method for managing whale populations. Foremost among the criticism is that the MSY encourages the harvesting of the largest of the species under protection. In addition it assumes that the environment has an unvarying influence on the species population. There are other methods of population management that compete with MSY, such as; Optimum Sustainable Yield (a method which would maximize economic rent), Yield Per Recruitment, Age Structured Models ( where the population is not tracked in totality but rather by age), Catch Limit Algorithm ( the catch limits are continually refined as more information regarding the population parameters become available), Strike Limit Algorithms (similar to catch limit algorithms but it is based on the number of whale "strikes" as opposed to the number of whales "landed").

\section{Conclusions}

The purpose of this paper is to address the question of when a competitive industry is engaged in the harvesting of a natural renewable resource and if that industry is left unregulated, will it continue to harvest that resource beyond its maximum sustainable yield. The American whaling industry of the 1800s was used as a counter factual study to address this point. Classical arguments along these lines suggests that regulation of common property renewable resources be held to a minimum since the marginal cost of harvesting will rise as the resource is depleted. This will cause the price to rise in a competitive industry as the marginal cost of harvesting increases, thus choking off demand. As firms leave the industry, the renewable resource has time to repopulate back to sustainable levels. However, this paper demonstrates that other factors that impact the resource price also need to be considered.

The empirical results of this paper show that rising incomes due to America's rapid industrialization of the 1800s was great enough to put upward pressure on demand and prices to keep the whalers chasing fewer and fewer whales. The results show that eventually, all other factors remaining the same, the whaling industry would have eventually increased harvesting beyond the maximum sustainable yield, thus jeopardizing the baleen whale populations.

A number of factors need to be kept in mind, however, when considering this point. First, it took nearly two decades for incomes to rise high enough to generate sufficient demand for the whaling industry to harvest such levels. Had the discovery of petroleum in Titusville, Pennsylvania been delayed from 1859 to 1880 , for instance, then it is just as conceivable that another product superior to whale oil 
could have been developed. In fact, coal oil was being refined just prior to 1859 and that could have replaced sperm and whale oil as the primary oil for illumination and lubrication.

Although rising incomes would take nearly two decades to generate enough demand to put the baleen whale population at risk, this time frame cannot be inferred upon all other renewable or non renewable resources. Demand factors, such as rising incomes could take a considerable shorter time. It would all depend on the income elasticity of the product in question.

Second, in the case of the American whaling industry technical advances were, for the most part, static. There were no significant improvements with respect to harvesting for the industry from the 1830s on. Improvements in technology, such as harpoon cannons or steamships outfitted for whaling were never adopted by the American whaling industry until well after the demise of the industry. Had the industry been aggressive in adopted improved harvesting techniques then it is more than likely the time frame associated with rising incomes would have been shorter.

Finally, and most importantly, it is important to consider the increasing marginal harvesting cost factor for either renewable or non renewable resources. The American whaling industry was unique in the fact that labor was paid a percentage of the harvest. Owners did not have to directly concern themselves with rising marginal costs. Their only concern was whether or not they could find enough crew members for a voyage. To address this variable this study uses as a proxy for the index of wages for unskilled workers during the 1800s. If labor was receiving less pay due to smaller revenues either from a decreasing price on the harvest or a reduction in the harvest itself, then higher wages in alternative employment opportunities would make it difficult for owners to attract crew members for a voyage.

In this analysis the alternative employment opportunities did have a significant impact on the whaling industry and the quantity of whales harvested. However, this was found to be significant only after the introduction of petroleum products onto the market. This was not found to be the case prior to 1859 when whale oil prices were still high. Had prices of whale oil remained high after the introduction of petroleum, then perhaps alternative employment opportunities would not have had a significant impact on the industry just as was the case before the introduction of petroleum onto the markets.

There are other demand factors to take into consideration, such as population growth or increases in international trade due to globalization. With respect to the analysis on whale oil, population growth appeared to be insignificant, but that might not be the case with all common property resources. The insignificance of population growth is attributed to the high level of correlation between GDP per capita and population.

\section{References and Notes}

1. Clark, C.W. Profit maximization and the extinction of animal species. J. Polit. Econ. 1973, 81, 950-961.

2. Bardi, U. Energy prices and resource depletion: Lessons from the case of whaling in the nineteenth century. Energ. Source Part B 2007, 2, 297-304.

3. Coleman, J.L. The American whale oil industry: A look back to the future of the American petroleum industry? Nat. Resour. Res. 1995, 4, 273-288.

4. Perman, R.; Ma, Y.; McGilray, J. Natural Resource and Environmental Economics; Longman Publishing: New York, NY, USA, 1996. 
5. Applebome, P. They used to say whale oil was indispensible too. New York Times, 8 March 2008.

6. Davis, L.E.; Gallman, R.E.; Hutchins, T.D. Technology, productivity, and profits: British-American whaling competition in the North Atlantic. Oxford Econ. Pap. 1987, 39, 738-759.

7. Williamson, H.F.; Andreano, R.L.; Menezes, C. The American Petroleum Industry. In Studies in Income and Wealth; National Bureau of Economics Research (NBER): Cambridge, MA, USA, 1966; Volume 30, pp. 349-404.

8. Tower, W.S. A History of the American Whale Fishery; University of Pennsylvania Press: Philadelphia, PA, USA, 1907.

9. U.S. Bureau of the Census. Historical Statistics of the United States, Colonial Times to 1970; U.S. Government Printing Office: Washington, DC, USA, 1976.

10. Davis, L.E.; Gallman, R.E.; Hutchins, T.D. Call Me Ishmael-Not Domingo Floresta: The Rise and Fall of the American Whaling Industry. In Research in Economic History; Mokyr, J., Ed.; JAI Press: Greenwich, CT, USA, 1991; Supplement 6, pp. 191-233.

11. Conrad, J.M. Bioeconomics and the Bowhead Whale. J. Polit. Econ. 1989, 97, 974-987.

12. Davis, L.E.; Gallman, R.E.; Hutchins, T.D. Productivity in American Whaling: The New Bedford Fleet in the Nineteenth Century. In Markets in History: Economic Studies of the Past; Galenson, D., Ed.; Cambridge University Press: New York, NY, USA, 1989.

13. Scarff, J.E. The international management of whales, dolphins, and porpoises: An interdisciplinary assessment. Ecol. Law Quart. 1977, 6, 323-427.

14. Allen, R.K. Conservation and Management of Whales; University of Washington Press: Seattle, WA, USA, 1980.

15. Davis, L.E.; Gallman, R.E.; Hutchins, T.D. The decline of U.S. whaling: Was the stock of whales running out? Bus. Hist. Rev. 1988, 62, 569-595.

16. Rice, D.W.; Wolman, A.A. The Life History and Ecology of the Grey Whale; American Society of Mammalogists: Lawrence, KS, USA, 1971; Pub. No. 3.

17. Roman, J.; Palumbi, S.R. Whales before whaling in the North Atlantic. Science 2003, 301, 508-510.

18. Allen, R.; Keay, I. The first great whale extinction: The end of the bowhead whale in the Eastern Artic. Explor. Econ. Hist. 2001, 38, 448-477.

19. Cole, A.H. Wholesale Commodity Prices in the United States, 1700-1861; Harvard University Press: Cambridge, MA, USA, 1938.

20. Bezanson, A. Wholesale Prices in Philadelphia, 1852-1896; University of Pennsylvania Press: Philadelphia, PA, USA, 1954.

21. Johnston, L.; Williamson, S.H. What was the U.S. GDP then? Measuring Worth, 2010; Available online: http://www.measuringworth.org/usqdp/ (accessed on 1 July 2009).

(C) 2010 by the authors; licensee MDPI, Basel, Switzerland. This article is an open access article distributed under the terms and conditions of the Creative Commons Attribution license (http://creativecommons.org/licenses/by/3.0/). 